\title{
Conventional and Critical Constructivist Approaches to National Security: An Analytical Survey
}

Cho, Young Chul*

(Yonsei University)

$\langle$ CONTENTS〉

I. Introduction

II. Conventional Constructivist Security Studies

III. Culture and Identity in Constructivist Security Studies
IV. Critical Constructivist Security Studies

V. Conclusion

- Keywords : security, identity, culture, Constructivism, meta-theory

\section{【ABSTRACT】}

This article aims to consider two different (or contentious) constructivist approaches to national security in the study of international relations: conventional constructivist security studies, on the one hand, and critical constructivist security studies on the other. In so doing, this article will examine both constructivisms' main assumptions and core concepts, such as norms, socialization, identity, culture, identity/difference, discourse, and so on. Of these concepts, special attention is paid to the concepts of "culture" and "identity" by investigating the question of how conventional and critical constructivists understand those concepts in crucially different ways in their respective researches relating to national security. The key difference -- to be exact, tension -- between the two variants of constructivism is that identities are often treated as explanatory variables for certain security phenomena in conventional constructivism, but in critical constructivism the identities themselves are to be explained to make sense of the cultural productions of insecurities.

\footnotetext{
*I am very grateful to William A. Callahan, Christopher R. Hughes, Shogo Suzuki, and the anonymous reviewers of KJIR for their helpful comments. All errors in this article are, of course, my responsibility. Email: youngchul.cho@gmail.com.
} 


\section{I . Introduction}

It is widely accepted that constructivism has become one of the most influential recent theoretical developments in International Relations (IR). ${ }^{1)}$ However, constructivism in IR should not been seen as one single, homogeneous theoretical perspective. Rather, owing to the diverse backgrounds and different meth-theoretical positions, "There are many constructivists, and thus perhaps many constructivisms" ${ }^{2)}$ in $\mathrm{IR}^{3)}$. Despite arbitrariness of any classification of constructivism (and all different theoretical perspectives), for the sake of pedagogical simplicity and analytical clarity, this article accepts Ted Hopf's much-sited distinction between "conventional" constructivism and "critical" constructivism in IR. ${ }^{4)}$ The fault lines between these constructivisms are largely based on their partly overlapped, but different meta-theoretical stances. According to Hopf, "Constructivism itself should be understood in its conventional and critical variants, the latter being more closely tied to critical social theory. ... [conventional constructivism] is a collection of principles distilled from critical social theory but without the latter's more consistent theoretical or epistemological follow-through." ${ }^{5)}$ In a similar vein, Reus-Smit also argues that "Constructivism is divided ... between those who remain cognizant of the critical origins and potentiality of their sociological explorations, and those who have embraced constructivism simply as an explanatory or interpretive tool." ${ }^{6)}$ With this in mind, this article aims to consider conventional and critical constructivist security studies oriented around the theme of national security. ${ }^{7)}$ In so doing, this article also examines both constructivisms' main assumptions and core concepts, such as norms, socialization, identity, culture, identity/difference, and discourse. In particular, this

1) As for the background to the advent and evolution of constructivism in IR, see Barnett (2005) and Reus-Smit (2005).

2) Price and Reus-Smit (2000), p. 1811.

3) Also see Hopf, 1998; Katzenstein, Keohane, and Krasner (1998); Ruggie (1998); Adler (2002); Reus-Smit (2005).

4) Regarding general commonalities and differences between conventional and critical constructivism, see Hopf (1998), pp. 181-185. To grasp more in-depth meta-theoretical contention between them, see Campbell (1998), pp. 207-227 and the Forum on Alexander Wendt in Review of International Studies, 26(1), 2000.

5) Hopf (1998), p. 172, p. 181.

6) Reus-Smit (2005), p. 204.

7) It should be noted that this article does not address, what Fierke (2007, p. 174) calls, "consistent constructivism" (or linguistic constructivism) which distinguishes itself from (and is critical of) both conventional constructivism's positivist epistemology (particularly, Wendtian constructivism) and critical constructivism's non- or anti-essentialist ontology (particularly, poststructuralism). For more about consistent constructivism, see Fierke (2007). 
article addresses the question of how meta-theoretically dissimilar (or contentious) conventional and critical constructivists understand their two key concepts -- "culture" and "identity" -- in importantly different ways in their respective writings of security studies. As for its structure, this article first examines the main arguments and concepts of conventional constructivist security studies through the exploration of some of its key texts in IR. It then explores conventional and critical constructivist different understandings of "culture" and "identity" in their researches. Finally, by screening some of its key texts in IR, the author scrutinizes the basic assumptions of critical constructivist security studies, along with some of its important concepts.

\section{Conventional Constructivist Security Studies}

In reviewing the literature on non-traditional security studies, apart from the poststructuralist security studies, Smith suggests two major conventional constructivist volumes. ${ }^{8)}$ One is Security Communities (1998), edited by Emanuel Adler and Michael Barnett, and the other is Peter J. Katzenstein's edited volume, The Culture of National Security: Norms and Identity in World Politics (1996). This article considers the latter, whose central theme -- "security interests are defined by actors who respond to cultural factors" ${ }^{9)}$-- is closely tied to the subject matter of national security. As can be seen from the title of Katzenstein's edited book, in its cultural approach to national security, conventional constructivism makes much account of the "norms" and "identity" in world politics. Here, we first examine the conventional constructivist understanding of the norms in international relations, particularly in comparison with the mainstream realist and liberalist treatments of the international norms.

Although realists do not totally ignore the ideational aspects of the international system, such as the institutions and orderly procedures, ${ }^{10)}$ for the most part, they treat norms as either secondary or unimportant, under anarchy in a materialist sense. ${ }^{11)} \mathrm{A}$ good starting point for establishing the realists' view of the norms is their discussion of international cooperation. Realism, albeit pessimistic, believes that international cooperation may happen if great powers make it happen. This thinking is evident in hegemonic stability theory, which argues that a hegemon is required to guarantee a

\footnotetext{
8) Smith (2004), pp. 38-40.

9) Katzenstein (1996a), p. 2.

10) Waltz (1979), p. 114.

11) Lamy (2005), p. 215.
} 
liberal, free-trade international political economy. This means that stable international regimes ${ }^{12)}$ rely on the hegemon setting up conventions and rules and then policing their functioning by an enlightened use of its power to persuade other states to abide by the regimes. ${ }^{13)}$ The power and interests of the hegemon, in the form of coercion and inducement, play a key role in the creation, reproduction, diffusion, and change of international regimes. Hence, regarding international cooperation, what matters in realism is the power (especially, the material capabilities) and interests of states rather than the international regimes themselves under anarchy. In a similar vein, Strange argues that international institutions (including regimes and organizations) merely reflect the surface of the underlying power relations, and those are trivial as causes of collective outcomes. ${ }^{14)}$ Overall, it can be said that realists treat the norms as epiphenomenal, and the role of ideas remains silent in realism. ${ }^{15)}$

Compared with realism, liberalists suggest a more sophisticated account of the international norms, with an emphasis on the role of ideas. According to liberalism, international cooperation is possible without hegemonic countries, because the anarchical nature of the international system is mitigated by the regimes whose roles are to monitor the actors' behaviors, to lower the transaction costs, to provide information, and even to enforce certain penalties or incentives, thereby precipitating international cooperation under anarchy. ${ }^{16)}$ In this respect, institutions can be defined as "persistent and connected sets of rules (formal and informal) that prescribe behavioral roles, constrain activity, and shape expectations. ${ }^{17)}$ Liberalism seems to show the relative autonomy of normative structures in international relations, treating regimes as apparatuses for facilitating the utility of agents whose interests were taken as given. ${ }^{18)}$ In brief, liberalism believes that norms have regulative effects that map out the standards of proper behavior among states in international relations, and ideas matter in the relations between the international normative structures and the states' behavior.

Nevertheless, in the eyes of conventional constructivism in IR, the rationalist (both realist and liberalist) treatment of norms as epiphenomenal or regulatory is only half

12) Regimes here refer to "sets of implicit or explicit principles, norms, rules, and decision-making procedures around which actors' expectations converge in a given area of international relations" (Krasner quoted in Little, 2005, p. 373).

13) Keohane (1989), pp. 74-100; Katzenstein, Keohane, and Krasner (1998), pp. 660-1.

14) Strange (1983).

15) Hobson (2000), p. 147.

16) Keohane (1984), p. 57, pp. 85-109; (1988), pp. 386-9; (1989).

17) Keohane (1989), p. 3.

18) Keohane and Nye (2001), p. 17. 
the story; because rationalism does not examine interests in relation to the effects of norms. They just assume interests. ${ }^{19)}$ This leads us to overlook an important facet of the state's national security -- the state identity. For example, rationalism has difficulty in explaining the following questions: although North Korea remains a primary threat to South Korea ${ }^{20)}$ why has South Korea shifted from a strong realist security policy stance towards North Korea (prevalent before the 1990s) to a reconciliatory one? And why has South Korea simultaneously shown hawkish and reconciliatory attitudes towards North Korea since the end of the Cold War? To address these questions properly, it is necessary to examine the international normative environment and South Korea's state identity as being related closely to the national interests.

Unlike realism, whose perspective is mainly based on the materialist thoughts on geopolitics, conventional constructivism argues that "the security environments in which states are embedded are in important part cultural and institutional, rather than just material." ${ }^{21)}$ Note that, however, conventional constructivism does not claim that material conditions are unimportant; rather "their impact is always mediated by the ideas that give them meaning." ${ }^{22)}$ For conventional constructivists, therefore, the role of ideas is crucial in constructing social life, and this idealist approach to international politics is centrally concerned with the social rather than the material. Unlike liberalists, who focus on the regulative role of norms, according to conventional constructivism, when we treat norms in the sociologically standard way, such as "collective expectations about proper behavior for a given identity," ${ }^{33)}$ they have a deeper effect. "Norms ... either define (or constitute) identities or prescribe (or regulate) behavior, or they do both. ${ }^{24)}$ Conventional constructivism further maintains that norms inform states of what they should do as well as what they are supposed to wish for; at an even deeper level, it affects what states believe they should be. ${ }^{25)}$ From this perspective, taking the relations between norms and state identity seriously, conventional constructivism can properly address "the content and source of state interests and social

19) Finnemore (1996a), p. 157.

20) Even after the historical June 2000 summit between the leaders of the two Koreas, the South Korean Defense Minister (MND, 2000, p. 1), clearly stated that "even with the recent positive changes in South-North relations, it must be noted that the reality of North Korea' s threat, with its powerful military, still exists. We will make our utmost effort to ensure military readiness at all times."

21) Jepperson, Wendt, and Katzenstein (1996), p. 33.

22) Fearon and Wendt (2002), p. 57.

23) Jepperson, Wendt, and Katzenstein (1996), p. 54.

24) Katzenstein (1996a), p. 5.

25) Muller (2002), p. 381. 
fabric of world politics, ${ }^{26)}$ which have been ignored by rationalism. The point is that the state identity is shaped through norms suggesting appropriate behaviors, which, in turn, constructs its particular interests. Norms thus constitute as well as affect states, providing them with knowledge of their interests. ${ }^{27)}$

Yet it is fair to say that, influenced by the constructivist Alexander Wendt's discussion on the agent-structure problem, ${ }^{28)}$ neoliberal institutionalism is aware that norms are not only regulative but also constitutive. Nonetheless, Robert Keohane, a leading neoliberal institutionalist, argues that Wendt's "abstractly valid point should not be pushed too far" because, in modern international relations, given the intensity of international institutions' impact on state policy, international "social structures," such as norms, are feeble in comparison with those of small united communities or even of modern national societies. ${ }^{29)}$ In a similar theoretical vein and a more developed form, categorizing ideas as world views, principled beliefs, and causal beliefs, Goldstein and Keohane suggest that ideas (serving as road maps, focal points, and glue for cooperation) and institutionalization have causal weight in explaining human action, as interests do. ${ }^{30}$ ) This view, however, is still narrow and confining, since the relation between ideas and interests remains unspecified. Moreover, due to the liberalist preoccupation with norms as regulative, although liberalists take ideas and norms into account, there is almost no room for discussing the constitutive dimension of norms and the formation, content, and source of the state's interests.

In line with the aforementioned conventional constructivist account of norms in relation to identity and interests, The Culture of National Security concentrates on two social elements, which are often ignored in rationalism, shaping national security policy: "the cultural-institutional context of policy on the one hand and the constructed identity of states, governments, and other political actors on the other. ${ }^{\text {11) }}$ The volume, then, focuses on "the effects that culture and identity have on national security." ${ }^{22}$ More specifically, in a theoretical chapter in The Culture of National Security, the analytical framework of conventional constructivist security studies are neatly illustrated as follows: ${ }^{\cdot 33)}$

\author{
26) Checkel (1998), p. 324. \\ 27) Checkel (1998), p. 326. \\ 28) Wendt (1987). \\ 29) Keohane (1989), p. 2, p. 6. \\ 30) Goldstein and Keohane (1993). \\ 31) Katzenstein (1996a), p. 4. \\ 32) Katzenstein (1996a), p. 17. \\ 33) Jepperson, Wendt, and Katzenstein (1996), pp. 52-3.
}


1. Effects of norms (I). Cultural or institutional elements of states' environments [norms] ... shape the national security interests or (directly) the security policies of states.

2. Effects of norms (II). Cultural or institutional elements of states' global and domestic environments [norms] ... shape state identity.

3. Effect of identity (I). Variation in state identity, or changes in state identity, affect the national security interests or policies of states.

4. Effect of identity (II). Configurations of state identity affect interstate normative structures, such as regimes or security communities.

5. Recursivity. State policies both reproduce and reconstruct cultural and institutional structure.

It seems clear in the lines of argument that the role of norms matters in the regulative as well as constitutive contexts. Above all, norms have a powerful hold on shaping identities which "strongly imply a particular set of interests or preferences with respect to choices of action in particular domains, and with respect to particular actors. ${ }^{34)}$ In other words, identities and interests are shaped by norms which lead actors to follow certain socially prescribed conduits of appropriate behavior -- what is often called, "the logic of appropriateness." It should, however, be noted that norms do not determine action but "create permissive conditions for action." ${ }^{35)}$ The state must act according to its identity and as its interests direct. It should also be remembered that we cannot reduce identities to norms: "Indeed, states adopting particular identities are more likely to conform to some norms over others." ${ }^{36)}$ Overall, in taking norms and state identity seriously, the authors in The Culture of National Security illustrate that states face security choices, and act upon them, not only on the basis of the material conditions but also in the context of the collective understanding among states.

The above conventional constructivist lines of argument are again rendered in Alexander Wendt's well-known theoretical work of conventional constructivism, Social Theory of International Politics, where he argues that "Interests presuppose identities ... Identity change and structural change are not equivalent ... but the latter supervenes on the former." ${ }^{37}$ In a crude form, therefore, the schema of conventional constructivism can be depicted as follows: cultures (or norms) $\Rightarrow$ collective identity $\Rightarrow$ states' interests and

34) Hopf (1998), p. 175.

35) Finnemore (1996a), p. 158.

36) Chafetz, Spirtas, and Frankel (1998/9), p. xvii.

37) Wendt (1999), p. 231, p. 338. 
policies. This schema reveals that conventional constructivists are inclined to place more weight on causation and structure than constitution and agent, despite their emphasis on the mutual constitution between agent and structure, as exemplified in Wendt's famous phrase, "Anarchy is what states make of it." ${ }^{\text {" I }}$ It is thus unsurprising that "The authors in this volume [The Culture of National Security] are thoroughgoing structuralists: they are interested in how structures of constructed meaning, embodied in norms or identities, affect what states do. ${ }^{\left.{ }^{99}\right)}$ Conventional constructivism could be regarded as "a kind of "structural idealism"., ${ }_{40}$

One of the clearest expressions of this is found in Martha Finnemore's volume, National Interests in International Society. ${ }^{41)}$ In conducting three case studies, the volume argues that, across its cases, the norms reified in the international institutions have guided states to reappraise what their national interests were and embrace the behavior recognized by these institutions as appropriate even when there was no concrete material incentive for that choice. This means that international normative structures can shape state policy, and thus the role of ideas and social structures matters in international relations. Due to her emphasis on the international normative structures, however, Finnemore's constructivist research has produced a similar outcome as that proposed by neorealism: as international environments have a strong top-down effect on many states worldwide, the internally different states select similar foreign policies and thus appear to be functionally similar. In this sense, in accounting for state behavior, Finnemore's logic of appropriateness hardly makes a difference from the rationalist logic of consequences. Part of the reason for this is that, in National Interests in International Society, domestic factors are of little importance. ${ }^{42}$

Yet, conventional constructivist are concerned with the effects of social structures not only at the international level, but also at the domestic one. In examining Japanese economic and security policies, Katzenstein and Okawara argue that, when analyzing foreign policy choice rather than systemic outcomes, what is important is not the international structures but the domestic ones. ${ }^{43)}$ Katzenstein also argues that the systemic theory of international politics is unable to capture the complex relations within the state structure itself because it 'black-boxes' the state. ${ }^{44)}$ As each state has

\author{
38) Wendt (1992). \\ 39) Jepperson, Wendt, and Katzenstein (1996), p. 66. \\ 40) Wendt (1999), p. 1. \\ 41) Finnemore (1996b). \\ 42) Checkel (1998), p. 332. \\ 43) Katzenstein and Okawara (1993), pp. 85-6. \\ 44) Katzenstein (1996b).
}


different domestic configurations of their own, this, in practice, often leads them to select different foreign policy choices within the given international system. Following on from this, Katzenstein also argues that an understanding of Japan's domestic normative arrangements help to explain Japan's behavior which appears contradictory and unreachable to neorealism focusing on the international system. ${ }^{45)}$ Again, in spite of drawing attention to the internal, domestic determinants of state behavior, Katzenstein's focus still remains on the significance of institutionalized constitutive and regulatory national social and legal norms (structure), subscribing to the conventional constructivist simple schema, as mentioned before.

As we have seen so far, conventional constructivism tends to treat social structure (norms) as an explanatory variable in the context of positivist social science on which rationalism is based. In fact, in "adopt[ing] a traditional, narrow definition of security studies," ${ }^{46)}$ The Culture of National Security prefers to engage in "normal science." ${ }^{47)}$ Likewise, the Social Theory of International Politics sides with positivist epistemology. ${ }^{48}$ In a broad analytical sense, therefore, there is a "complementary relationship" between conventional constructivism and rationalism. Conventional constructivists explain that the "norms and identity fill gaps where other [mainstream] perspectives fall short" ;9) for example, conventional constructivists do "the work of explaining how actors gain their preferences" through the impact of norms on their identities and rationalists look at "how they realize those preferences" in a strategic situation. ${ }^{50)}$

As for the structuralist stance of conventional constructivism, which is more concerned with causation than constitution, we need to consider one critical question: if norms really matter in international politics, as conventional constructivism points out, what are the sources of these norms (or where do they come from)? It is paradoxical that, while they criticize rationalists for treating state identity and interests as exogenously given, conventional constructivists themselves take their own core concepts for granted. ${ }^{51)}$ Although it basically maintains that the structures of international politics are sustained or transformed by the states' practice and interaction, ${ }^{52)}$ regarding the process of norms construction, conventional constructivism has relatively little to say.

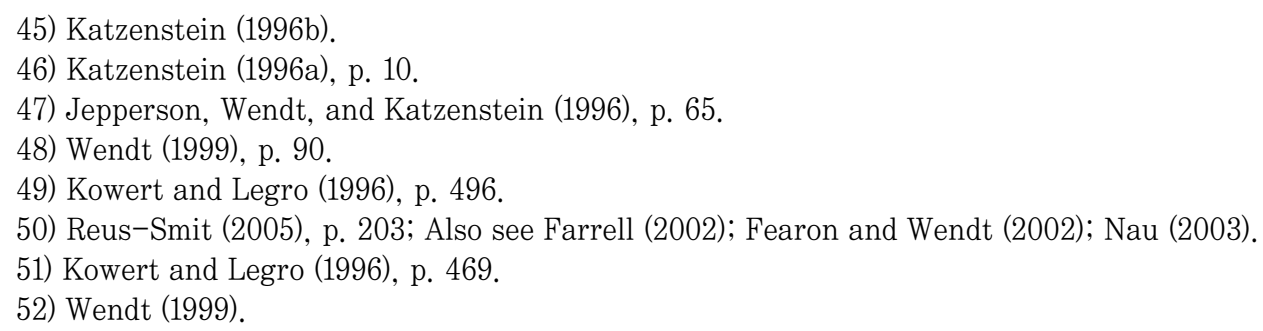


This is partially due to the fact that conventional constructivism appears to make little of the power differentials between states in the formation of international norms. In the self-reflective chapter in The Culture of National Security, as Kowert and Legropertinently point out that, "some agents are clearly able to use norms in an instrumental fashion to further their own interests rather than simply being held captive to various normative mandates." ${ }^{53)}$ In a more critical stance, Cox also argues that "Institutionalization is a means of stabilizing and perpetuating a particular order ... Institutions [or norms] may become the anchor for such a hegemonic strategy since they lend themselves both to the representations of diverse interests and to the universalization of policy." ${ }^{54)}$ International norms are neither neutral nor innocent. Power and norms, for the most part, are reciprocally supportive, and thus they often imply each other.

It is thus important to bear in mind the power differentials between states, particularly when examining the mutual constitution between the international security environments and security practices of relatively weak countries, for it is clear that small or middle powers are often subject (willingly or unwillingly) to the directions of the existing norms sustained by the great powers. Arguably, "anarchy is not what states make of it but what great powers make of it." ${ }^{55)}$ It is thus naive to ignore the influential role of the great powers and power differentials among states in a liberal sense, when looking at the construction and maintenance of the norms affecting the state identities and interests in international politics.

\section{Culture and Identity in Constructivist Security Studies}

In contrast to rationalism, both conventional and critical constructivisms take the concepts of culture and identity seriously in world politics. It is thus important to explore the two concepts in more depth in order to make better sense of both the conventional and critical constructivisms as analytical lenses for national security in empirical research. More specifically, we should examine how the two different constructivisms differently understand the two important concepts in their own researches, which will highlight the feud between conventional and critical constructivists. According to Katzenstein, the conventional constructivist essays in The Culture of

53) Kowert and Legro (1996), p. 492.

54) Cox (1986), p. 219.

55) J.H. Yang (2001), p. 40. 
National Security make sense and use of norms, identity, and culture as follows: ${ }^{\cdot 56}$

The authors use the concept of norm to describe collective expectations for the proper behavior of actors with a given identity. ... Norms thus either define (or constitute) identities or prescribe (or regulate) behaviour, or they do both. ... The essays refer to identity as a shorthand label for varying constructions of nation and statehood. ... the authors in this volume invoke the term culture as a broad label that denotes collective models of nation-state authority or identity, carried by custom or law. Culture refers to both a set of evaluative standards (such as norms and values) and a set of cognitive standards (such as rules and models) that define what social actors exist in a system, how they operate, and how they relate to one another.

Considering the description of the three concepts, it is easy to raise one critical question: in what sense does culture differ decisively from norms? It would seem that, in The Culture of National Security, 'the term 'culture' is too inclusive and undifferentiated ... [furthermore] Katzenstein's definition of culture almost collapses into his definition of norms." ${ }^{57)}$ Yet, in developing a theory of "the international system as a social construction," the Social Theory of International Politics ${ }^{58)}$ conceptualizes the term "culture" in a more sophisticated form and more practical terms. According to Wendt, ${ }^{59)}$

culture is a self-fulfilling prophecy, i.e., actors act on the basis of shared expectations, and this tends to reproduce those expectations. ... Culture is constantly in motion, even as it reproduces itself. It is what people make of it, even as it constrains what they can do at any given moment. It is an on-going accomplishment. Despite having a conservative bias, therefore, culture is always characterized by more or less contestation among its carriers, which is a constant resource for structural change.

On this basis, Wendt offers three different cultures of anarchy in the international system, rendered as Hobbesian, Lockean, and Kantian, respectively. ${ }^{60)}$ Each culture is constructed by a particular idea of the basic relationship among many states. A state may see its other as an enemy (Hobbesian culture), rival (Lockean culture), or friend

56) Katzenstein (1996a), pp. 4-6.

57) Onuf (1998), p. 133; also see Tamamoto (2003), pp. 194-195.

58) Wendt (1999).

59) Wendt (1999), p. 42, p. 188.

60) Wendt (1999), pp. 246-312. 
(Kantian culture). In addition, three degrees of cultural internalization (coercion, selfinterest, and legitimacy), which express the different levels of commitment to a prevailing international culture, cut across the three cultures above. As a result, the three cultures as shared ideas differently inform state identity and interests, and produce different tendencies in the international system. Above all, cultural change (for example, from the Hobbesian to Lockean culture) "involves the emergence of new forms of collective identity [among states], and so it is on the determinants of the latter." ${ }^{{ }_{11}}$ Related to the cultural change, socialization (i.e., the adoption of rules and modes of behavior by agents) emerges as an important concept in conventional constructivism, because identities and interests are constructed through socialization from the culture. ${ }^{62)}$ In this respect, "socialization is the central "causal" process for constructivists that links structures to agents and back again." ${ }^{\left.{ }_{63}\right)}$ This implies a conventional constructivist focus on the logics of appropriateness.

Considering the above discussion on the conventional constructivist treatment of culture, despite admitting that culture is always in process and changeable, it appears to be static and conservative. More to the point, conventional constructivism tends to treat culture as an independent substance (or a set of things) which "determines a predominant self-identity of a specific and sizeable collective of people [or states]." ${ }^{\left.{ }_{44}\right)}$ Viewed in this way, culture matters in national security as well as in international relations, since it decides to what extent states feel secure or insecure in the international system, which is a social construction. Against conventional constructivism, critical constructivism treats culture as less static and more context-sensitive. In one of the major critical constructivist volumes in security studies, Cultures of Insecurity, Weldes et al. describe culture as follows: ${ }^{65}$

Culture can ... be thought of as encompassing the multiplicity of discourses or "codes of intelligibility" ... through which meaning is produced -- including discourses about "culture" itself. This multiplicity in turn implies ... that meanings can be contested. We thus understand culture to be composed of potentially contested codes and representations, as designating a field on which are fought battles over meaning.

This critical constructivist rendering reveals that culture is not a fully formed

61) Wendt (1999), p. 44.

62) Reus-Smit (2005), pp. 198-199.

63) Johnston (2003), p. 109; also see Wendt (1999), pp. 324-336.

64) Shaffer (2006), p. 2.

65) Weldes et al. (1999), pp. 1-2. 
substance which we can measure its impact on state identity and interests, but is "a site of meaning production," ${ }^{66)}$ which itself needs to be explained while paying heed to how meanings relating to (in)security are produced, reproduced, and altered. Critical constructivism sees culture as "in need of ideological excavation," ${ }^{67)}$ with respect to the cultural process of meaning production.

Along with the term 'culture', another key concept in constructivist security studies is 'identity', particularly 'state identity'. In IR theory, how to understand state identity is a hot topic of severe contention between conventional and critical constructivism, revealing their different meta-theoretical stances and ethical commitments to IR. In the Social Theory of International Politics, Wendt discusses four sorts of identity: 1) corporate; 2) type; 3) role; and 4) collective. ${ }^{68)}$ Of these kinds of identity, attention should be directed to corporate and collective identities ${ }^{69}$ in order to grasp the tension between conventional and critical constructivists. According to Wendt, corporate (or in the case of individuals, personal) identities "are constituted by the self-organizing, homeostatic structures that make actors distinct entities. ... states as actors with certain essential properties concerns this kind of identity." ${ }^{70}$ This identity always possesses a material base; for example, people and land for states. More importantly, corporate identity as a purposive actor's identity has an awareness and memory of Self as a distinct site of thought and activity. In this sense, members of a state have joint narratives of themselves as a corporate agent, and, to that extent, corporate identity takes the collective identity of individuals as fact. The formation of the state's corporate identity is more internal than external, which is often bound up with constructing nationalism aimed at consolidating internal cohesion. Hence, the state as a 'group Self' is capable of group-level cognition. ${ }^{71}$ Subsequently, by imputing anthropomorphic properties, like desires, beliefs, and intentionality, onto the state, the above understanding of corporate identity can allow conventional constructivists to take the ontology of states for granted in international relations: "states are ontologically prior to the states system, [and the] state is presocial relative to other states in the same way that the human body is pre-social." ${ }^{22)}$ This indicates that, in conventional constructivism, the state as an intentional actor is essentialized, and the corporate identity is understood as the foundational identity

66) Weber (2005), p. 6.

67) Klotz and Lynch (2007), p. 13.

68) Wendt (1999), pp. 224-233.

69) For detailed definitions of type and role identities, see Wendt (1999), pp. 224-233.

70) Wendt (1999), pp. 224-5.

71) Wendt (1999), p. 215, p. 225.

72) Wendt (1999), p. 198. 
which is "a site or platform for other identities." ${ }^{\text {73) }}$ In the same sense, the sociological thrust of The Culture of National Security's argument is based on the ontological idea that "nation-state actors are somehow contextless or ultimately 'real'." ${ }^{44)}$ However, against IR rationalism which is based on the thick essentialism regarding a state's ontology, conventional constructivism strips down the state, arguing that many of the properties often assumed to be inherent to states (such as power-seeking, egoism, the meaning of power, the terms of sovereignty, and so on) are, in fact, contingent, shaped by the international system. ${ }^{75)}$ Overall, regarding state identity, conventional constructivists defend a minimalist vision of foundational (or essentialist) theory.

Compared with conventional constructivists, in seeking a deeper understanding of state identity, critical constructivists see the state as open and malleable, and have a non-essentialist view of its subjectivity. For critical constructivists, the state cannot exist of its own accord, for it has no ontological foundation apart from the many discursive practices of self/other and inclusion/exclusion that bring it into being. As Weber argues, the sovereign state "is the 'ontological effect of practices which are performatively enacted'... 'sovereign nation-states are not pre-given subjects but subjects in process." "76) In the parallel non-essentialist sense, Campbell also argues that "states are never finished as entities ... states are (and have to be) always in a process of becoming." As a consequence, in Anderson's terms, the state (or nation) is "imagined" in the sense that it does not exist as a complete and exclusive unity, given that it is unceasingly performing: ${ }^{.78)}$ "there is statecraft, but there is no completed state." ${ }^{\text {"9) }}$ What emerges here is the key ontological difference (or tension) between the conventional and critical constructivists: "whether we want to take the constitution and nature of agency seriously ... or whether we are happy in the final instance to merely posit the importance of certain agents." ${ }^{80}$

Based on the above critical constructivist stance, Smith argues that, as states are "pre-social" and ontologically pregiven in the Social Theory of International Politics, "Wendt's account of the foreign policy behavior of states leaves no room for domestic factors." ${ }^{81)}$ It thus seems that, in Wendt's constructivism, states' identities and interests

\footnotetext{
73) Wendt (1999), p. 195, pp. 197-8, p. 201, p. 225.

74) Jepperson, Wendt, and Katzenstein (1996), p. 71.

75) Wendt (1999), p. 198, p. 245.

76) Weber (1998), p. 78.

77) Campbell (1998), p. 12.

78) Anderson (1991).

79) Devetak (2005), p. 181.

80) Campbell (1998), p. 220.

81) Smith (2001), pp. 50-51.
} 
are produced and altered through social interactions with one another in the international system, rather than as a consequence of occasions in their foreign policy decisionmaking processes. As for Wendt's conceptualization of state identity, Zehfuss also argues that "Wendt's anthropomorphic concept of the state cannot cope with identities which are unstable in themselves" and that Wendt overlooks "the constitution of states as subjects in the first place." ${ }^{82)}$ Zehfuss further argues that Wendt's rendering of relatively stable and circumscribable state identities "threatens to undermine the possibility of his constructivism." ${ }^{83)}$ From a critical constructivist point of view, conventional constructivism is unable to interrogate the practices that constitute the states themselves, particularly the state's corporate identity which is intrinsically linked to the question of what is to be secured.

In the Social Theory of International Politics, however, in focusing on not capturing the formation of state identity but building a social theory of the international system, ${ }^{84}$ the corporate identity issue is largely toned down: "systems of states presuppose states, and so if we want to analyze the structure of those systems we cannot 'de-center' their elements all the way down." ${ }^{85)}$ Due to this author's academic interest in the international system, in the Social Theory of International Politics, Wendt pays special attention to collective identity which "is a distinct combination of role and type identities, one with the causal power to induce actors to define the welfare of the Other as part of that of the Self, to be 'altruistic'. Altruistic actors may still be rational, but the basis on which they calculate their interests in the group or 'team." " ${ }^{86)}$ Related to this, Wendt's typology of an enemy (Hobbesian), rival (Lockean), and friend (Kantian) implies a certain collective identity among states. As such, the collective identity is the crucial intersubjective meanings that construct the international system. This identity emerges from social interaction, and perhaps changes through social interactions in international relations. States interacting in a given culture come to know one another as the bearers of certain identities. When this happens, the states appeal to certain prospects as to each other's actions based on these identities. ${ }^{87)}$ In this respect, the collective identity subsumes reputation; having a particular collective identity is enough to supply the necessary

82) Zehfuss (2001), p. 335, p. 337.

83) Zehfuss (2001), p. 316.

84) Throughout the book, Wendt (1999, p. 11), repeatedly argues that "Like Waltz, I am interested in international politics, not foreign policy. ... in fact explaining state identities and interests is not my main goal either. This is a book about the international system, not about state identity formation."

85) Wendt (1999), p. 244.

86) Wendt (1999), p. 229.

87) Kahl (1998/9), pp. 104-5; Wendt (1999). pp. 318-343. 
diagnostic information about a state's likely behavior with reference to other states in particular cultures. ${ }^{88}$ ) On this basis, conventional constructivism (more specifically, Wentian constructivism) is mainly concerned with structures and their effects on agents (changes in the distribution of collective identity) in taking the state itself (corporate identity) for granted in international relations.

\title{
IV. Critical Constructivist Security Studies
}

As discussed earlier, critical constructivists assume that "the state has no ontological status apart from the many and varied practices that bring it into being, then the state is an artefact of a continual process of reproduction that performatively constitutes its identity." ${ }^{89)}$ In this non-essentialist sense, critical constructivists believe that producing, reproducing, and patrolling the state identity is vital to its stability and security. To interrogate the practices that (re)produce the state itself, making sense of the notion of identity/difference is essential in critical constructivist security studies. In his edited book, Identity and Difference, as Woodward mentions, "identity is most clearly defined by difference, that is what it is not." ${ }^{90)}$ More to the point, identity is constructed in relation to difference. Difference, in turn, is constructed in relation to identity. It, then, reveals that identities are relational and contingent rather than essential and fixed: namely, identity depends on difference, and vice versa. Against this backdrop, identity should be understood as a production, "which is never complete, always in process, and always constituted within, not outside, representation." ${ }^{91)}$ Through this never-ending process, identities are "performatively constituted." ${ }^{22}$

In the notion of identity/difference, it is also important to remember that, although difference itself does not necessarily mean something bad or inferior at first hand, and indeed can be welcomed as a source of diversity, often difference is negatively defined in relation to identity. As for this tendency, William Connolly points out, in his landmark volume, Identity/Difference, that "The definition of difference is a requirement built into the logic of identity, and the construction of otherness is a temptation that readily insinuates itself into that logic." ${ }^{93)}$ In practice, in making sense of the Self, the Other

\author{
88) Hopf (1998), p. 190. \\ 89) Campbell (2003), p. 57. \\ 90) Woodward (1997a), p. 2. \\ 91) Hall quote in Woodward (1997b), p. 51. \\ 92) Campbell (1998), p. 9. \\ 93) Connolly (2002), p. 9.
}


often tends to be defined as something inferior or even insane rather than as equal or simply different, thus indicating that Self needs to keep the Other at bay. This line of reasoning reveals that, to make the Self (identity) more pure and essential, otherness should be excluded and marginalized. At this juncture, the constitution of the identity is achieved through "the interior/exterior (inside/outside) binary according to which that which is inside is deemed to be the self, good, primary, and original while the outside is the other, dangerous, secondary, and derivative." ${ }^{94)}$

Accordingly, as long as we do not question the Self's moral superiority, the general status of the Self tends to be superior to the Other. Furthermore, as Shapiro mentions, "to the extent that the Other is regarded as something not occupying the same natural/ moral space as the self, conduct toward the Other becomes more explosive." ${ }^{95}$ If this is the case, violence towards the Other is already legitimated. Even genocide or ethnic cleaning can be possible when the Other human beings are represented as 'radical nonselves' or 'the subhuman' who are totally outside any moral inhibition. ${ }^{96)}$ Apart from otherness as the exclusion and marginalization of those who are on the outside, there is another important attitude towards difference: that is, domesticating that which is different. This does not mean that the process of converting difference into sameness is peaceful; rather, it could be coercive. In fact, "Assimilation and otherness are two faces of the same issue: dealing with difference ... Both reconfirm an embattled identity. ${ }^{97)}$

As for the constitution of the subject, as discussed so far, "Identity requires difference in order to be, and it converts difference into otherness in order to secure its own selfcertainty." ${ }^{98)}$ In this argument, at first glance, differences are constitutive of a selfidentity. Yet, differences are, at the same time, disruptive in the sense that they have a tendency to "counter, resist, overturn, or subvert definitions applied to them," ${ }^{99}$ thereby encroaching on the identity that they supposedly shape. Hence, to prevent a crisis of identity, there is always a politics of sameness and difference "through which difference can, but need not, be transformed into otherness. When it is, it becomes a source of insecurity." ${ }^{100)}$ After all, identity is not only constituted but also disrupted in relation to difference, both constantly and simultaneously: "Madness [difference] and its corollaries [otherness] stand in a double relation to normality [self-identity]: they constitute it and

94) Campbell (2007), p. 215.

95) Shapiro (1988), p. 102.

96) Messari (2001), p. 235.

97) Messari (2001), p. 230.

98) Connolly (2002), p. 64.

99) Connolly (2002), p. 64.

100) Weldes et al. (1999), p. 11. 
they threaten it." ${ }^{101)}$ To sum up, identity is defined by differences which are underpinned by exclusion. Moreover, this identity/difference nexus produces an implication for critical constructivist security studies: "security depends upon insecurities."

Based on the notion of identity/difference as a powerful analytical tool in world politics, in a theoretical chapter in the Cultures of Insecurity, Weldes et al. nicely illustrate critical constructivism' s basic substantive assumption as follows: "insecurities, rather than being natural facts, are social and cultural productions. ... insecurity is itself the product of processes of identity construction in which the self and the other, or multiple others, are constituted. ... identity and insecurity are produced in a mutually constitutive process." ${ }^{103)}$ In this context, critical constructivists argues that identities themselves are to be explained to make sense of the cultural production of (in)securities, rather than treating them as explanatory variables affecting national security, as conventional constructivists do. In line with this, the authors in the Cultures of Insecurity focus on addressing the question of "how the cultural production of insecurities implicates and is implicated in the cultural production of the identities of actors." ${ }^{104)}$

In her empirical essay on the Cultures of Insecurity, Weldes offers a novel way of grasping the well-known Cuban missile crisis in 1962. ${ }^{105)}$ Unlike traditional security studies, rather than seeing the Soviet missile deployment in Cuba as a real, objective, and self-evident threat to the United States, Weldes argues that the crisis is "the product of an extended process of social construction." ${ }^{106)}$ Above all, the American identity as a leader of the free world was reasserted and secured by representing the Soviet missiles deployment in Cuba as a real danger and threat to U.S. national security. The crisis was socially constructed. The Cuban missile crisis in 1962 can thus be seen as a culturally constituted site, in which American identity was performed through the operation of foreign policy linked to the socially constructed external threat. Here, the important claim is that the construction of the Cuban missile crisis might close off or marginalized alternative constructions which may have defused the crisis.

Methodologically, the authors in the Cultures of Insecurity take "discourses of insecurity" as their targets of analysis and interrogate how they operate. ${ }^{107)}$ The main reason for this is that the performative constitution of identity takes place within

101) Connolly (2002), p. 67.

102) Callahan (2004), p. xxiv.

103) Weldes et al. (1999), pp. 10-11.

104) Weldes et al. (1999), p. 11.

105) Weldes (1999).

106) Weldes (1999), p. 37, pp. 59-60.

107) Weldes et al. (1999), p. 11. 
discourse. In Foucault's sense, discourse refers to a specific series of representations and practices involving meaning production which constructs the identities of subjects and objects. ${ }^{108)}$ Moreover, making discourse (or producing representation) is "an act of radical institution," ${ }^{109)}$ which involves the production of antagonisms and the inscription of political boundaries between inside/outside and domestic/foreign. In practice, the important role of discourses is to help to frame concrete guidelines on people's thoughts and deeds, especially when faced with contingencies and resistances: "discourses make certain things sayable, thinkable and doable but others not." ${ }^{110)}$ In so doing, particular meanings of the Self become taken for granted over time, creating formal and informal institutions which "set expectations about how the world works, what types of behaviour are legitimate, and which interests or identities are possible," ${ }^{111}$ which is associated with the process of socialization. Therefore, although identities are "context-bound instantiations" in perpetual progress, "political discourse consists, among other things, of essentializing representations of identities. " ${ }^{122}$ In this respect, in and through the hegemonic discourse, the dominant realities are socially constructed and the essential cores of identities often appear to exist of their own accord.

Here, it is also necessary to remember an important ethical commitment of critical constructivism in the pursuit of learning as an IR scholar, in comparison with that of conventional constructivism. For conventional constructivists, social constructivism is "analytically neutral," ${ }^{113)}$ like rational choice theory, and thus the conventional constructivist project "is not to change the world, but to understand it." ${ }^{14)}$ The purpose of conventional constructivism is to produce knowledge about world politics and add to the mainstream debate in IR. ${ }^{115)}$ On the contrary, critical constructivists tend to regard theory as practice, arguing that "A critical constructivist approach denaturalizes dominant constructions, offers guidelines for the transformation of common sense, and facilitate the imaging of alternative life-worlds." ${ }^{116)}$

In parallel with the Cultures of Insecurity, David Campbell's Writing Security ${ }^{117}$ underpins the critical constructivist approach to national security. ${ }^{118)}$ Like other critical constructivist

108) Hall (1997); Howarth (2000).

109) Howarth (2000), p. 9.

110) Abercrombie, Hill, and Turner (2000), p. 99.

111) Klotz and Lynch (2007), p. 8.

112) Neumann (1999), p. 212.

113) Jepperson, Wendt, and Katzenstein (1996), p. 39.

114) Farrell (2002), p. 72.

115) Jepperson, Wendt, and Katzenstein (1996); Farrell (2002).

116) Weldes et al. (1999), p. 13.

117) Campbell (1998). 
work, Campbell does not regard the state as a pre-given unified actor in international politics, examining how the identity of America has been produced and reproduced through foreign policies operating in its name. ${ }^{119)}$ In his book, therefore, the U.S. state is understood as an ongoing performance, and its state identity is the effects of diverse and multiple practices that operate in the service of American ideals. Foreign policy is one of the major official identity practices performed by and for the state, and, thus, U.S. foreign policy does not simply serve the national interest, but helps to construct and reconstruct the American identity which, in turn, informs its national interests and behavior.

Moreover, rather than clarifying and analyzing a concrete threat to national security, as do scholars of traditional security studies, Campbell regards danger as "an effect of interpretation," and further argues that "Danger constitutes more than the boundary that demarcates a space; to have a threat requires enforcing a closure on the community that is threatened." ${ }^{120)}$ Based on this non-essentialist perspective, Writing Security examines how the "discourses of danger," which are integral to foreign policy, secure the boundaries of the U.S. state identity. The discourses of danger provide the state with a set of apparent truths about "who and what 'we' are by highlighting who or what 'we' are not, and what 'we' have to fear." ${ }^{121)}$ The discourses are often accompanied by the strategies of otherness toward the constructed enemies out there and internal dissidence/difference, in order to secure the domestic in intrinsical connection with the foreign: "the ability to represent things as alien, subversive, dirty, or sick has been pivotal to the articulation of danger in the American experience." ${ }^{122)}$ Through constructing the very moral (and territorial) domains of the inside/outside, Self/Other, and domestic/ foreign, the discourses of danger serve to discipline the state, coping with new occurrences

118) Arguably, Cultures of Insecurity is theoretically based on critical social constructivism, whereas Writing Security is called the work of poststructuralism. Although the two volumes are different in terms of how radical they should be in relation to the mainstream IR scholarship, they are analytically very akin and are intellectually allied (Campbell, 1998, pp. 207-277; Marcus, 1999, pp. vii-xix). In this article, the term 'critical constructivism' is understood in a broad sense, ranging from critical social constructivism to poststructuralism. It should also be noted that critical IR theory is not one single enterprise, although different critical IR scholars commonly make mainstream rationalism problematic. One camp (critical theory) has employed its critical project in the context of "emancipation," and the other camp (poststructuralism) has been suspicious of any kind of designed project in the name of "progress" and "modernity." See Devetak (1995) and Rengger and Thirkell-White (2007).

119) Campbell (1998), p. x.

120) Campbell (1998), p. 2, p. 73.

121) Campbell (1998), p. 48.

122) Campbell (1998), p. 3. 
of ambiguity or contingency. The constant representation of danger often produces some substantive outcomes as follows: 1) enabling the construction of a certain crisis, in order to foster the internal consolidation of the state power; 2) marginalizing other alternatives to transcending the existing relations of power through (re)affirming the existing state identity; 3) making people believe that the state's actions (often followed by violence) to its defined Others are legitimate; and 4) providing people with guidelines about how to see, render, and behave toward their state and the enemies of the state, and so on. In addition, Writing Security shows that U.S. foreign policy has relied on a specific series of representations of danger, and, through enacting its foreign policy, the boundaries of the state are constituted, reconstituted, policed and patrolled. This was not merely based on some Cold War inevitability but is a perpetual trait of U.S. foreign policy. Accordingly, after the collapse of the Soviet Union, drugs and rouge states were emerged as new officially identified discourses of danger, in order to end the post-Cold War crisis of U.S. identity.

Last but not least, regarding the connection (and interplay) between the stateinitiated foreign policy and political identity, Campbell offers two different senses of foreign policy. ${ }^{123)}$ First, foreign policy (italic $f$ and $p$ ) refers to all of the boundary-making practices. These practices stand for, to varying degrees and at all different levels, any kind of political, cultural, and social projects and processes which convert difference into otherness. This is not necessarily based on a state's initiatives. On the other hand, Eoreign Policy (capital F and P) is regarded as state-rooted and conventionally understood within the IR discipline, such as South Korea's Sunshine Policy. It is thus one of the boundary-making practices central to constitution, reconstitution, and patrol of the state identity in whose name it operates at the level of the state. Foreign Policy as a fundamental part of the discourses of danger is the crucial form of exclusion that polices the state as we find it. How are, then, foreign policy and Foreign Policy interrelated? When examining Foreign Policy in relation to national security and state identity, it is important to understand foreign policy because it provides "the discursive economy or conventional matrix of interpretations" ${ }^{124)}$ in which the Foreign Policy operates. This indicates that Eoreign Policy does not implicate in the constitution of identity on a par with foreign policy, and Foreign Policy cannot be regarded as "constituting identity de novo." ${ }^{125)}$ Rather, Foreign Policy serves "to reproduce the constitution of identity made possibly by" foreign policy and "to contain challenges to

123) Campbell (1998), pp. 61-72.

124) Campbell (1998), p. 69.

125) Campbell (1998), p. 68. 
the identity that results." ${ }^{126)}$ Therefore, we should not underestimate the bond between Foreign Policy and political identity. Given the interplay between foreign policy and Eoreign Policy, it would seem that high politics and the official (such as Eoreign Policy) cannot exist in isolation, and they should engage with a dialogue with low politics and the popular/the cultural -- a crucial site of foreign policy -- to secure their plausibility in any given nation-state. It is in this respect that high politics and popular culture are intrinsically related sites implicating each other, and thus the analytical scope of traditional security studies should not ignore the low politics of popular culture in order to make better sense of what they really concern -- national security and high politics.

\section{Conclusion}

Taking identity and culture seriously in world politics, constructivism has become one of the most influential recent theoretical developments in IR since the end of the Cold War. Yet, there are, broadly speaking, two different constructivisms in IR according to their different meta-theoretical stances: conventional constructivism, on the one hand, and critical constructivism on the other. In security studies, an analytical framework of conventional constructivism is elaborated in Peter J. Katzenstein's edited volume, The Culture of National Security, while that of critical constructivism is expounded in Jutta Weldes et al.'s edited volume, Cultures of Insecurity. The central theme of conventional constructivism is that "security interests are defined by actors who respond to cultural factors." ${ }^{127)}$ In this process, "The concept of "identity' ... functions as a critical link between environmental structures and interests." ${ }^{128)}$ On the other hand, critical constructivism rests on the principal assumption that "insecurity is itself the production of processes of identity construction in which the self and the other, or multiple others, are constituted." ${ }^{129)}$ It is thus argued that identities and insecurities themselves are not pregiven and natural things which exist separately, but "are produced in a mutually constitutive process." ${ }^{130)}$ The key difference between these two constructivisms is that identities are often treated as explanatory variables for certain security phenomena in conventional constructivism, but in critical constructivism the identities themselves are to be

126) Campbell (1998), p. 69.

127) Katzenstein (1996a), p. 2.

128) Jepperson, Wendt, and Katzenstein (1996), p. 59.

129) Weldes et al. (1999), p. 10.

130) Weldes et al. (1999), p. 11. 
explained to make sense of the cultural productions of insecurities. Despite this difference (or tension) between conventional and critical constructivists, there is no need to treat the two constructivisms as opposite or conflicting across the board. Rather, both constructivisms can be regarded as complementary while we understand national security in relation to identity and culture. Indeed, no single perspective can fully capture the complexity of world politics in the post-Cold War era of globalization. Both conventional and critical constructivisms help us to make deeper sense of world politics in crucially different ways. 


\section{REFERENCES}

Abercrombie, Nicholas, Stephen Hill, and Bryan S. Turner. The Penguin of Dictionary of Sociology. London: Penguin, 1999.

Adler, Emanuel. "Constructivism in International Relations," in Walter Carlsnaes, ed. Handbook of International Relations. London: Sage, 2002.

Anderson, Benedict. Imagined Communities: Reflections on the Origin and Spread of Nationalism. New York: Verso, 1991.

Barnett, Michael. "Social Constructivism," in John Baylis and Steve Smith, eds. The Globalization of World Politics: An Introduction to International Relations. Oxford: Oxford University Press, 2005.

Callahan, William A. Contingent States: Greater China and Transnational Relations. Minneapolis: University of Minnesota Press, 2004.

Campbell, David. Writing Security: United States Foreign Policy and the Politics of Identity. Manchester: Manchester University Press, 1998.

. "Cultural Governance and Pictorial Resistance: Reflections on the Imaging of War." Review of International Studies 29 (2003), pp. 57-73.

. "Poststructuralism," in Tim Dunne, Milja Kurki, and Steve Smith, eds. International Relations Theories: Discipline and Diversity. Oxford: Oxford University Press, 2007.

Chafetz, Glenn, Michael Spirtas and Benjamin Frankel. "Introduction: Tracing the Influence of Identity on Foreign Policy.” Security Studies 8 (1998/9), pp. vii-xxii.

Checkel, Jeffrey T. "The Constructivist Turn in International Relations Theory." World Politics 50 (1998). pp. 324-348.

Connolly, William E. Identity/Difference: Democratic Negotiations of Political Paradox. Minneapolis: University of Minnesota Press, 2002 (Expanded Edition).

Cox, Robert W. "Social Forces, States and World Orders: Beyond International Relations Theory," in Robert O. Keohane, ed. Neorealism and Its Critics. New York: Columbia University Press, 1986.

Devetak, Richard. "The Project of Modernity and International Relations Theory." Millennium 24 (1995), pp. 27-51.

"Postmodernism," in Scott Burchill et al., eds. Theories of International Relations. Basingstoke: Palgrave, 2005. 
Farrell, Theo. "Constructivist Security Studies: Portrait of a Research Program." International Studies Review 4 (2002), pp. 49-72.

Fearon, James and Alexander Wendt. "Rationalism v. Constructivism: A Skeptical View," in Walter Carlsnaes, ed. Handbook of International Relations. London: Sage, 2002.

Fierke, K.M. "Constructivism," in Tim Dunne, Milja Kurki, and Steve Smith, eds. International Relations Theories: Discipline and Diversity. Oxford: Oxford University Press, 2007.

Finnemore, Martha. "Constructing Norms of Humanitarian Intervention," in Peter J. Katzenstein, ed. The Culture of National Security: Norms and Identity in World Politics. New York: Columbia University Press, 1996a.

National Interests in International Society. Ithaca: Cornell University Press, 1996b.

Goldstein, Judith and Robert O. Keohane. "Ideas and Foreign Policy: An Analytical Framework," in Judith Goldstein and Robert O. Keohane, eds. Ideas and Foreign Policy: Beliefs, Institutions, and Political Change. Ithaca: Cornell University Press, 1993.

Hall, Stuart. "The Work of Representation," in Stuart Hall, ed. Representation: Cultural Representation and Signifying Practices. London: Sage Publications, 1997.

Hobson, John M. The State and International Relations. Cambridge: Cambridge University Press, 2000.

Hopf, Ted. "The Promise of Constructivism in International Relations Theory." International Security 23 (1998), pp. 171-200.

Howarth, David. Discourse. Buckingham: Open University Press, 2000.

Jepperson, Ronald L., Alexander Wendt, and Peter J. Katzenstein. "Norms, Identity, and Culture in National Security," in Peter J. Katzenstein, ed. The Culture of National Security: Norms and Identity in World Politics. New York: Columbia University Press, 1996.

Johnston, Alastair Iain. "Socialization in International Institutions: The ASEAN Way and International Relations Theory," in G. John Ikenberry and Michael Mastanduno, eds. International Relations Theory and the Asia-Pacific. New York: Columbia University Press, 2003.

Kahl, Colin H. "Constructing a Separate Peace: Constructivism, Collective Liberal Identity, and Democratic Peace.” Security Studies 8 (1998/9), pp. 94-144. 
Katzenstein, Peter J. "Introduction: Alternative Perspectives on National Security," in Peter J. Katzenstein, ed. The Culture of National Security: Norms and Identity in World Politics. New York: Columbia University Press, 1996a.

Cultural Norms and National Security: Police and Military in Postwar Japan. Ithaca: Cornell University Press, 1996b.

Katzenstein, Peter J., ed. The Culture of National Security: Norms and Identity in World Politics. New York: Columbia University Press, 1996.

Katzenstein, Peter J., Robert O. Keohane, and Stephen Krasner. "International Organization and the Study of World Politics." International Organization 52 (1998), pp. 645-685.

Katzenstein, Peter J. and Nobuo Okawara. "Japan's National Security: Structures, Norms, and Policies." International Security 17 (1993), pp. 84-118.

Keohane, Robert O. After Hegemony: Cooperation and Discord in the World Political Economy. Princeton: Princeton University Press, 1984.

"International Institutions: Two Approaches." International Studies Quarterly 32 (1988), pp. 379-396.

International Institutions and State Power: Essays in International Relations Theory. Boulder: Westview Press, 1989.

Keohane, Robert O. and Joseph S. Nye. Power and Interdependence. New York: Longman, 2001.

Klotz, Audie and Cecelia Lynch. Strategies for Research in Constructivist International Relations. Armonk: M.E. Sharpe, 2007.

Kowert, Paul and Jaffrey Legro. "Norms, Identity, and Their Limits: A Theoretical Reprise," in Peter J. Katzenstein, ed. The Culture of National Security: Norms and Identity in World Politics. New York: Columbia University Press, 1996.

Lamy, Steven L. "Contemporary Mainstream Approaches: Neo-realism and $\mathrm{Neo}^{-}$ Liberalism," in John Baylis and Steve Smith, eds. The Globalization of World Politics: An Introduction to International Relations. Oxford: Oxford University Press, 2005.

Marcus, George. "Foreword," in Jutta Weldes et al., eds. Cultures of Insecurity: States, Communities, and the Production of Danger. Minneapolis: University of Minnesota Press, 1999.

Messari, Nizar. "Identity and Foreign Policy: The Case of Islam in U.S. Foreign Policy," in Vendulka Kubalkova, ed. Foreign Policy in a Constructed World. London: M.E. Sharpe, 2001. 
MND (Ministry of National Defense, The Republic of Korea). Defense White Paper. Seoul: Ministry of National Defense, 2000.

Muller, Harald. "Security Cooperation," in Walter Carlsnaes, ed. Handbook of International Relations. London: Sage, 2002.

Nau, Henry R. "Identity and the Balance of Power in Asia," in G. John Ikenberry and Michael Mastanduno, eds. International Relations Theory and the Asia-Pacific. New York: Columbia University Press, 2003.

Neumann, Iver B. Uses of the Other: "The East" in European Identity Formation. Manchester: Manchester University Press, 1999.

Onuf, Nicholas. "The New Culture of Security Studies." Mershon International Studies Review 42 (1998), pp. 132-134.

Price, Richard and Christian Reus-Smit. "Dangerous Liaisons? Critical International Theory and Constructivism," in Andrew Linklater, ed. International Relations: Critical Concepts and Political Science. London: Routledge, 2000.

Rengger, Nicholas and Ben Thirkell-White "Introduction: Still Critical after All These Years? The Past, Present, and Future of Critical Theory in International Relations." Review of International Studies 33 (2007), pp. 3-24.

Reus-Smit, Christian. "Constructivism," in Scott Burchill et al., eds. Theories of International Relations. Basingstoke: Palgrave, 2005.

Ruggie, John Gerard. Constructing the World Polity: Essays on International Institutionalization. London: Routledge, 1998.

Shaffer, Brenda. "Introduction: The Limits of Culture," in Brenda Shaffer, ed. The Limits of Culture: Islam and Foreign Policy. Cambridge: The MIT Press, 2006.

Shapiro, Michael J. The Politics of Representation: Writing Practices in Biography, Photography, and Policy Analysis. Madison: University of Wisconsin Press, 1988.

Smith, Steve. "Foreign Policy Is What States Make of It: Social Construction and International Relations Theory," in Vendulka Kubalkova, ed. Foreign Policy in a Constructed World. London: M.E. Sharpe, 2001. "The Contested Concept of Security," in Ken Booth, ed. Critical Security Studies and World Politics. Boulder: Lynne Rienner, 2004.

Strange, Susan. "Cave! Hic Dragones: A Critique of Regime Analysis," in Stephen D. Krasner, ed. International Regimes. Ithaca: Cornell University Press, 1983.

Tamamoto, Masaru. "Ambiguous Japan: Japanese National Identity at Century's End," in G. John Ikenberry and Michael Mastanduno, eds. International Relations Theory and the Asia-Pacific. New York: Columbia University Press, 2003. 
Waltz, Kenneth. Theory of International Politics. Reading: Addison-Wesley, 1979.

Weber, Cynthia. International Relations Theory: A Critical Introduction. Abingdon: Routledge, 2005. "Performative States." Millennium 27 (1998), pp. 77-95.

Weldes, Jutta. "The Cultural Production of Crises: U.S. Identity and Missiles in Cuba," in Jutta Weldes et al., eds. Cultures of Insecurity: States, Communities, and the Production of Danger. Minneapolis: University of Minnesota Press, 1999.

Weldes, Jutta, Mark Laffey, Hugh Gusterson, and Raymond Duvall. "Introduction: Constructing Insecurity," in Jutta Weldes et al., eds. Cultures of Insecurity: States, Communities, and the Production of Danger. Minneapolis: University of Minnesota Press, 1999.

Weldes, Jutta, Mark Laffey, Hugh Gusterson, and Raymond Duvall, eds. Cultures of Insecurity: States, Communities, and the Production of Danger. Minneapolis: University of Minnesota Press, 1999.

Wendt, Alexander. "The Agent-Structure Problem in International Relations Theory." International Organization 41 (1987), pp. 335-370.

. "Anarchy Is What State Make of It: The Social Construction of Power Politics." International Organization 46 (1992), pp. 391-425.

Social Theory of International Relations. Cambridge: Cambridge University Press, 1999.

Woodward, Kathryn. "Introduction," in Kathryn Woodward, ed. Identity and Difference. London: Sage Publications, 1997a.

. "Concepts of Identity and Difference," in Kathryn Woodward, ed. Identity and Difference. London: Sage Publications, 1997b.

Yang, Jun-Hee. "Wendt's Constructivism Challenges Waltz's Neorealism." The Korean Journal of International Relations 41 (2001) (In Korean), pp. 25-46.

Zehfuss, Maja. "Constructivism and Identity: A Dangerous Liaison." European Journal of International Relations 7 (2001), pp. 315-348. 